Technical Paper

\title{
Kinetic Analysis on Low-Temperature Steam Reforming of Methane Using a Ruthenium Supported Catalyst
}

\author{
Naotsugu ITOH ${ }^{* 1}$, Tasuku Yamamoto ${ }^{* 2}$, Takafumi SATO*1, W. YU*2, and Takao Ohmori ${ }^{* 2}$ \\ (Received July 4, 2005)
}

\section{ルテニウム担持触媒を用いたメタン低温水蒸気改質反応の速度解析}

伊藤直次 ${ }^{* 1}$, 山本 輔 $^{* 2}$, 佐藤剛史 ${ }^{* 1}, \mathrm{~W} . \mathrm{Yu}^{* 2}$, 大森隆夫*2

Reaction rates of methane steam reforming for hydrogen production at low temperatures $400-525^{\circ} \mathrm{C}$ were measured to establish the rate expression. A $2 \mathrm{wt} \%$ ruthenium supported alumina was used as a catalyst. As the measured rates were analyzed based on the Langmuir-Hinshelwood mechanism, it was found that the surface reaction between methane and water adsorbed was the rate-determining step and the following expression could well explain the kinetic data obtained experimentally.

$$
r=\frac{k}{\left(1+K_{\mathrm{CH}_{4}} P_{\mathrm{CH}_{4}}+K_{\mathrm{H}_{2} \mathrm{O}} P_{\mathrm{H}_{2} \mathrm{O}}+K_{\mathrm{H}_{2}} P_{\mathrm{H}_{2}}\right)^{4}}\left(P_{\mathrm{CH}_{4}} P_{\mathrm{H}_{2} \mathrm{O}}-\frac{P_{\mathrm{CO}_{2}} P_{\mathrm{H}_{2}}{ }^{4}}{K_{p}}\right)
$$

\section{Key Words}

Kinetics, Methane steam reforming, Reaction rate, Hydrogen

\section{1. 緒 論}

最近, 燃料電池のための水素製造技術として炭化水素の改 質反応が注目されているが，その中で最も広く取り上げられ ているのがメタンによる水蒸気改質反応である。この反応は 吸熱反応であり, 外部加熱方式では，一般的に耐熱性の高い $\mathrm{Ni}$ 担持アルミナ触媒を使用して反応温度 $800 \sim 1000^{\circ} \mathrm{C}$, 反応 圧力 $15 \sim 40$ 気圧という過酷な条件下で行われているのが現 状である。こうした高温を選ぶ理由は熱力学的平衡の制約を 軽減するためであるが, 水素製造の熱効率が問題となる場面 では，投入熱エネルギーの低減や水素分離精製を含めたプロ セス全体の簡素化が大きな課題となる。

そこで，こうした現状のプロセスに対し，水素分離精製を 同時に行うことのできる膜利用反応プロセスの提案がなされ ている ${ }^{122)}$ 。原理としては，1)改質反応触媒層に組み込んだ水 素選択分離膜を通して, 生成水素の反応系外一の引き抜きに より，水素分離を実現すると同時に，2)生成水素の選択分離 によって反応自身の脱平衡化が促進され, 低い反応温度でも 高い反応率が実現できるというものである。これによって, 改 質反応温度を一気に $500^{\circ} \mathrm{C}$ 前後まで下げることができれば，プ

* 1 Department of Applied Chemistry, Utsunomiya University 7-1-2, Yoto, Utsunomiya, Tochigi 321-8585, Japan

* 2 National Institute of Advanced Industrial Science and Technology

Central 5, 1-1-1, Higashi, Tsukuba, Ibaraki 305-8565, Japan
ロセスのシンプル化とともに省エネルギー化が期待できる。 ここでまず問題となるのは，低温領域でのメタンによる改 質反応を進めるにあたって，低温で活性な触媒の探索と反応 器設計に必要な反応速度解析（速度式）である。今回，低温 活性触媒としては，市販のルテニウム担持アルミナ触媒が良 い性能を有することが予備実験によって判り採用することに した。したがって, 本報告では低温域でのメタン水蒸気改質 反応をルテニウム触媒を用いて扮こない, その反応速度式を 提案することを目的とした。

2. メタンの水蒸気改質反応 ${ }^{3)}$ と触媒 $\left.{ }^{4)} \sim 6\right)$

メタンの水蒸気改質反応は, 以下 3 つの反応が関与すると されている。

$$
\begin{array}{ll}
\mathrm{CH}_{4}+\mathrm{H}_{2} \mathrm{O} \rightarrow \mathrm{CO}+3 \mathrm{H}_{2} & \Delta \mathrm{H}_{298}=206 \mathrm{~kJ} / \mathrm{mol} \\
\mathrm{CO}+\mathrm{H}_{2} \mathrm{O} \rightarrow \mathrm{CO}_{2}+\mathrm{H}_{2} & \Delta \mathrm{H}_{298}=-41 \mathrm{~kJ} / \mathrm{mol} \\
\mathrm{CH}_{4}+2 \mathrm{H}_{2} \mathrm{O} \rightarrow \mathrm{CO}_{2}+4 \mathrm{H}_{2} & \Delta \mathrm{H}_{298}=165 \mathrm{~kJ} / \mathrm{mol}
\end{array}
$$

これらの反応は, 温度, 圧力および $\mathrm{S} / \mathrm{C}$ 比 (水蒸気/メタン 投入モル比)によって生成物の組成が決まる平衡反応である。 反応 (1) は, 大きな吸熱反応であるため, 高温ほどCOおよび

\footnotetext{
* 1 宇都宮大学工学部応用化学科 干 321-8585 栃木県宇都宮市陽東 7-1-2

*2 (独) 産業技術総合研究所 干 305-8565 茨城県つくば市東 1-1-1 中央第 5
} 
$\mathrm{H}_{2}$ 生成量が大きくなる。一方, 反応 (2) は発熱反応であり, 低 温域で平衡的には有利になる。ただ， $500^{\circ} \mathrm{C}$ 近傍の低温で反応 を行う場合には $\mathrm{CO}$ の Boudouard 反応 $\left(2 \mathrm{CO}=\mathrm{C}+\mathrm{CO}_{2}\right)$ に よる炭素の析出にも注意を払う必要がある7)。

本研究での予備調查の結果，コーキングを抑えつつ高い活 性が得られる貴金属系触媒であるRuに着目した。RuはRhや 他の貴金属材料よりも比較的安価であり, 高分散であるため 含有量も数\%と低く抑元る事が可能であるため実用的である と思われる。

\section{3. 反応速度測定と速度モデル}

\section{1 微分型反応器による反応速度測定 $\left.{ }^{8)} \sim 10\right)$}

反応器の設計を行うにあたり必要な反応速度の決定を微分 型反応器を用いて行った。微分型反応器では, 触媒層の微小 体積変化に対する物質収支をもとに, 反応速度は以下のよう に表される。

$$
r=\frac{1}{F} \frac{d x}{d V}
$$

ここで，Vは触媒層体積 $\left[\mathrm{m}^{3}\right]$ あるいは触媒重量 $[\mathrm{kg}, \mathrm{g}]$ ， $\mathrm{F}$ は原料供給速度 $\left[\mathrm{mol} / \mathrm{s}, \mathrm{cm}^{3} / \mathrm{min}\right], \mathrm{r}$ は触媒単位重量あた りの反応速度 $[\mathrm{mol} /(\mathrm{kg}-\mathrm{cat} \cdot \mathrm{s})], \mathrm{x}$ は 無次元反応率 $[$ - $]$ で ある。式(4)より, 微分型反応器では, 反応速度は微小体積に 㧍ける反応率の微小変化及び原料供給速度の関数で表される ことから，一定触媒量のもと原料供給速度を変化させ，その 定常状態に捄ける反応速度を実測した。

\section{2 反応速度モデル}

\subsection{1 反応平衡計算}

反応速度実験㧍よび解析を行うにあたって反応進行度およ びその時の生成物の濃度 (分圧)を知る必要があり, 反応 (1) 〜 (3) に対する反応平衡計算を行った。Fig. 1 は, S/C = 3 で 各反応圧力に拈けるメタンの平衡反応率の $400 \sim 800^{\circ} \mathrm{C} に わ$ たって温度依存性をみたものである。反応圧力が低いほど，ま た反応温度が高いほど反応率が高くなることがわかる。次に

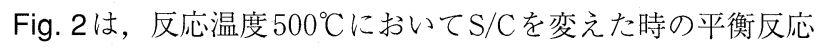

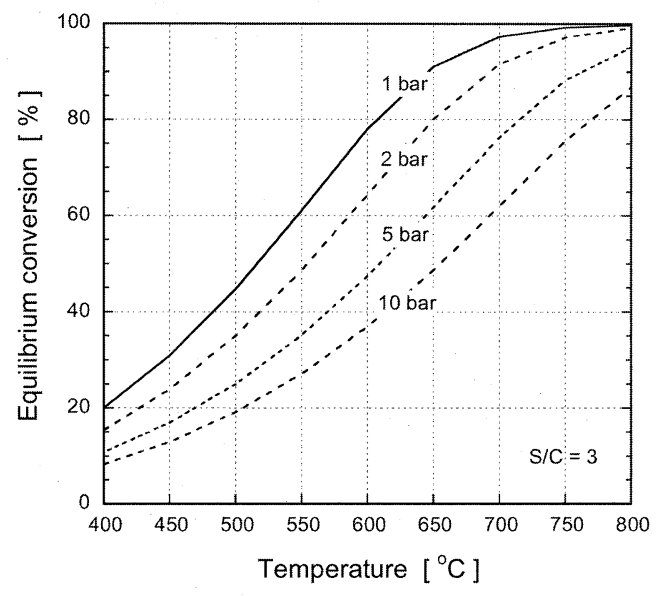

Fig. 1 Temperature dependence of equilibrium conversion for methane steam reforming

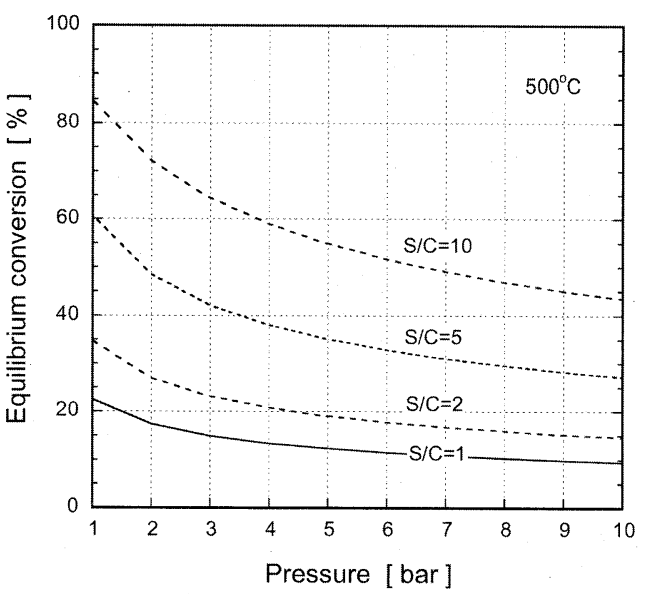

Fig. 2 Effect of S/C on equilibrium conversion for methane steam reforming

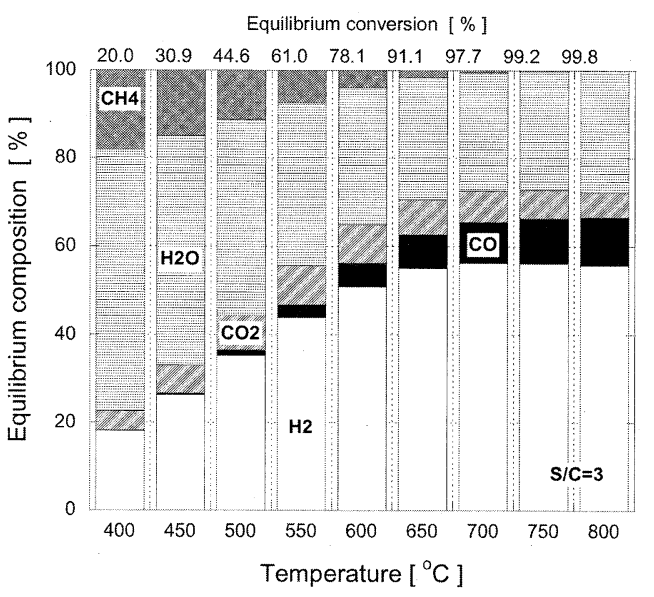

Fig. 3 Change of equilibrium composition with temperature

率の圧力依存性をみたものであるが， S/Cが大きく反応圧力が 低いほど反応率は高くなることがわかる。Fig.3は，S/C=3 の時の各温度での平衡組成を示したもので，高温になるにし たがい反応率は上昇するものの, 反応 $(2)$ の $\mathrm{CO}$ シフト反応が 平衡論的に進みにくくなってCO割合が増加する結果, 水素生 成割合 $\left(\mathrm{H}_{2} /\left(\mathrm{CO}_{2}+\mathrm{CO}\right)\right.$ 比) は特に $700^{\circ} \mathrm{C}$ 以上ではほとんど 増加しないことがわかる。

以上の平衡計算結果から, 反応の低温化はメタンの反応率 を低下させるものの, 反応 (2)すなわち一酸化炭素シフト反応 を生成側に有利に作用し, その結果水素生成割合すなわち $\mathrm{H}_{2} /$ $\left(\mathrm{CO}_{2}+\mathrm{CO}\right)$ 比を 4 に近づける効果があることがわかる。Fig. 3より明らかなように, $500^{\circ} \mathrm{C}$ 以下になれば, COの平衡組成は $1 \%$ 以下となり, シフト反応器を必要としないレべルになる と言える。また, 反応速度解析を考えた場合, 低温域ではCO 生成量が少ないことから, 反応(2) は速やかに進み, 総括的な 反応は反応(3)によって表されるとして良いと考え，以下では 反応 (3) に着目することとする。

\subsection{2 気相固体触媒反応}

Ni系触媒を用いたメタン水蒸気改質反応に対する気相系固 体触媒反応速度式については多くの提案がされている。まず 
簡易的に分圧のべき乗で表す反応速度式については，1）原料 のメ夕ン分圧の 1 次に比例する ${ }^{1112)}$ ，2）メタン分圧の 1 次に 比例し水素分圧に反比例する ${ }^{13)}$ とするものがあげられるが， 実験デー夕の範囲内での相関であるので適用範囲特に圧力条 件が限定されるようである。次に, 触媒表面上での吸着と反 応を考慮した速度式については多くの提案 ${ }^{14)}$ - 18) がある。こ の中でもXu，Fromentによって反応(1)〜 (3)に対して提案さ れた Langmuir - Hinshelwood 型の反応速度式 ${ }^{16 !}$ が利用ある いは修正して広く用いられている2１9－21)。

以上はNi系触媒に関するものであり, Ru系触媒については 少ないものの, Berman らの最近の解析例 ${ }^{22}$ がある。それに よると, $\mathrm{Ru}$ 上でのメタンと水蒸気の解離吸着を含む表面反応 に対して次の速度式を提案している。

$$
r=\frac{a P_{\mathrm{CH}_{4}}}{\left(b_{\mathrm{CH}_{4}} P_{\mathrm{CH}_{4}}+b_{\mathrm{H}_{2} \mathrm{O}} P_{\mathrm{H}_{2} \mathrm{O}}^{0.5}\right)}
$$

ここで，a は速度定数， bi は吸着に関する係数である。

一般に気相触媒反応は, 反応物への触媒活性点への気相本 体からの拡散, 吸着, 表面反応, 生成物の脱着, 気相本体へ の拡散の過程を経るとされているが，律速段階がどの過程に あるかによって速度式が決まってくる。ところで本研究で対 象にしているのは，通常 $800^{\circ} \mathrm{C}$ 以上で行われている改質反応を $500^{\circ} \mathrm{C}$ 前後で進行させることであり，低温化のために触媒も低 温活性が高いとされるルテニウム担持触媒を選んだ。低温で の反応の速度解析を行う場合，その律速過程は表面反応にあ ると考えられる。何故ならば，反応の活性化エネルギーは大 きく，低温ほど他の過程に比べて反応速度が小さくなると予 想されるためである。よって以下では, 表面反応律速としてい くつかの速度モデルを取り上げて，解析を進めることとした。

\section{2 .3 表面反応律速モデル}

反応ガスを Aとして，それが触媒表面の活性点に吸着した 活性種を $\mathrm{A} \cdot L$ と表わすことにする。メタンと水蒸気との反応 に対して想定される過程を MODEL I 〜 V によって表わした 時, 以下のようにそれぞれ反応速度式が導かれる ${ }^{8)}$ 。 MODEL Vとして，式(5)の検証も行った。

\section{MODEL I}

＜吸着メタンと吸着水蒸気との反応＞活性点において吸着メ 夕ンと吸着水蒸気との反応が起こり, 生成物の吸着はないも のとすると, 表面における反応は次のように書き表される。

$$
\begin{aligned}
& \mathrm{CH}_{4}+\mathrm{L} \Leftrightarrow \mathrm{CH}_{4} \cdot L \\
& \mathrm{H}_{2} \mathrm{O}+\mathrm{L} \Leftrightarrow \mathrm{H}_{2} \mathrm{O} \cdot \mathrm{L} \\
& \mathrm{CH}_{4} \cdot \mathrm{L}+2 \mathrm{H}_{2} \mathrm{O} \cdot \mathrm{L} \Rightarrow \mathrm{CO}_{2}+4 \mathrm{H}_{2}+3 \mathrm{~L}
\end{aligned}
$$

ここで, 吸着メタンと気相メタンとは平衡にあるものとする。 水蒸気についても同様である。上式に対する速度式は次のよ うになる。

$$
r=\frac{k^{\prime} K_{\mathrm{CH}_{4}} K_{\mathrm{H}_{2} \mathrm{O}}{ }^{2}}{\left(1+K_{\mathrm{CH}_{4}} P_{\mathrm{CH}_{4}}+K_{\mathrm{H}_{2} \mathrm{O}} P_{\mathrm{H}_{2} \mathrm{O}}\right)^{3}}\left(P_{\mathrm{CH}_{4}} P_{\mathrm{H}_{2} \mathrm{O}}{ }^{2}-\frac{P_{\mathrm{CO}_{2} P_{\mathrm{H}_{2}}}{ }^{4}}{K_{p}}\right)
$$

MODEL II

<吸着メ夕ンと吸着水蒸気との反応 (生成 $\mathrm{CO}_{2}$ の吸着) > 活性 点に括いてメタンと水蒸気との反応が起こり, 生成物の $\mathrm{CO}_{2}$ の吸着があるとすると, 表面における反応は次のように書き 表される。

$$
\begin{aligned}
& \mathrm{CH}_{4}+\mathrm{L} \Leftrightarrow \mathrm{CH}_{4} \cdot L \\
& \mathrm{H}_{2} \mathrm{O}+\mathrm{L} \Leftrightarrow \mathrm{H}_{2} \mathrm{O} \cdot \mathrm{L} \\
& \mathrm{CH}_{4} \cdot \mathrm{L}+2 \mathrm{H}_{2} \mathrm{O} \cdot L \Rightarrow \mathrm{CO}_{2} \cdot L+4 \mathrm{H}_{2}+2 \mathrm{~L} \\
& \mathrm{CO}_{2} \cdot \mathrm{L} \Leftrightarrow \mathrm{CO}_{2}+L
\end{aligned}
$$

ここで, 吸着メタン, 水蒸気, 二酸化炭素はそれぞれ気相の 各成分と吸着平衡にあるとする。上式に対する速度式は次の ようになる。

$$
\frac{r=}{\left(1+K_{\mathrm{CH}_{4}} P_{\mathrm{CH}_{4}}+K_{\mathrm{H}_{2} \mathrm{O}} P_{\mathrm{H}_{2} \mathrm{O}}+K_{\mathrm{CO}_{2}} P_{\mathrm{CO}_{2}}\right)^{3}}\left(P_{\mathrm{CH}_{4}} P_{\mathrm{H}_{2} \mathrm{O}}{ }^{2}-\frac{P_{\mathrm{CO}_{2} P_{\mathrm{H}_{2}}}{ }^{4}}{K_{\mathrm{D}}}\right)
$$

\section{MODEL III}

<吸着メタンと吸着水蒸気との反応 (生成 $\mathrm{H}_{2}$ の吸着) > 活性 点においてメタンと水蒸気との反応が起こり, 生成物の $\mathrm{H}_{2}$ の 吸着があるとすると，表面における反応は次のように書き表 される。

$$
\begin{aligned}
& \mathrm{CH}_{4}+\mathrm{L} \Leftrightarrow \mathrm{CH}_{4} \cdot \mathrm{L} \\
& \mathrm{H}_{2} \mathrm{O}+\mathrm{L} \Leftrightarrow \mathrm{H}_{2} \mathrm{O} \cdot \mathrm{L} \\
& \mathrm{CH}_{4} \cdot \mathrm{L}+2 \mathrm{H}_{2} \mathrm{O} \cdot \mathrm{L}+\mathrm{L} \Rightarrow \mathrm{CO}_{2}+4 \mathrm{H}_{2} \cdot L \\
& \mathrm{H}_{2} \cdot \mathrm{L} \Leftrightarrow \mathrm{H}_{2}+\mathrm{L}
\end{aligned}
$$

ここで, 吸着メタン, 水蒸気, 水素はそれぞれ気相の各成分 と吸着平衡にあるとする。上式に対する速度式は次のように なる。

$$
\begin{aligned}
& r= \\
& \frac{k^{\prime} K_{\mathrm{CH}_{4}} K_{\mathrm{H}_{2} \mathrm{O}}{ }^{2}}{\left(1+K_{\mathrm{CH}_{4}} P_{\mathrm{CH}_{4}}+K_{\mathrm{H}_{2} \mathrm{O}} P_{\mathrm{H}_{2} \mathrm{O}}+K_{\mathrm{H}_{2}} P_{\mathrm{H}_{2}}\right)^{4}}\left(P_{\mathrm{CH}_{4}} P_{\mathrm{H}_{2} \mathrm{O}}{ }^{2}-\frac{P_{\mathrm{CO} 2} P_{H_{2}}{ }^{4}}{K_{p}}\right)
\end{aligned}
$$

MODEL IV

$<$ 吸着メタンと気相水蒸気との反応 (生成水素の吸着) $>$ 上記 の吸着種同士の反応ではなく, 活性点に执いて吸着メタンと 気相からの水蒸気との反応も考えられる (Rideal機構)。生成 物の $\mathrm{H}_{2}$ の吸着があるとすると, 表面における反応は次のよう に書き表される。

$$
\begin{aligned}
& \mathrm{CH}_{4}+\mathrm{L} \Leftrightarrow \mathrm{CH}_{4} \cdot L \\
& \mathrm{CH}_{4} \cdot \mathrm{L}+2 \mathrm{H}_{2} \mathrm{O}+3 \mathrm{~L} \Rightarrow \mathrm{CO}_{2}+4 \mathrm{H}_{2} \cdot L \\
& \mathrm{H}_{2} \cdot L \Leftrightarrow \mathrm{H}_{2}+\mathrm{L}
\end{aligned}
$$

この場合, 厳密には Langmuir - Hinshelwood 型ではないが, 上述のモデルと同様に導出することができ, 次のような速度 式となる。

$$
r=\frac{k^{\prime} K_{\mathrm{CH}_{4}}}{\left(1+K_{\mathrm{CH}_{4}} P_{\mathrm{CH}_{4}}+K_{\mathrm{H}_{2}} P_{\mathrm{H}_{2}}\right)^{4}}\left(P_{\mathrm{CH}_{4}} P_{\mathrm{H}_{2}} \mathrm{O}^{2}-\frac{P_{\mathrm{CO}_{2} P_{H 2}}{ }^{4}}{K_{p}}\right)
$$


MODEL V

< Bermanらによるモデル $>\mathrm{Ru} / \mathrm{Al}_{2} \mathrm{O}_{3}$ 触媒に対する速度式 (5) について検証を行う。

なお，式(7)，(9)，(11)，(13）において，k’は反応速度定数 $[\mathrm{mol} / \mathrm{kg}-\mathrm{cat} \cdot \mathrm{s}], K_{n}$ は各成分の吸着平衡定数 $\left[\mathrm{Pa}^{-1}\right], P_{n}$ は 各成分の分圧 $[\mathrm{Pa}]$, r触媒単位質量あたりの反応速度 $[\mathrm{mol} /$ $\mathrm{kg}-\mathrm{cat} \cdot \mathrm{s}], K_{D}$ は平衡定数 $\left[\mathrm{Pa}^{2}\right]$ である。

\section{4. 実験装置および実験方法}

Fig. 4に実験装置の概略図を示す。反応器には石英製の管型 反応器 (内径 $15 \mathrm{~mm}$ ) を用いた。使用した触媒は，2.0wt\% Ru/ $\mathrm{Al}_{2} \mathrm{O}_{3}$ 担持触媒（ズードケミー製 $\mathrm{RUA}$ ) で，窒素吸着による 比表面積は $4.8 \mathrm{~m}^{2} / \mathrm{g}$ であった。このペレットを粒径約 0.5 $1.0 \mathrm{~mm}$ に粉砕調製したもの $0.1 \sim 0.2 \mathrm{~g}$ をぼ同粒径の石英ガ ラスとを約 $1: 3$ の比で混合し, 反応器にFig. 4のように充填 した。なお充填層の厚さは約 $3 \mathrm{~mm}$ であった。前処理として, $550^{\circ} \mathrm{C}$ において水素ガス $\left(25 \% \mathrm{H}_{2}-\mathrm{N}_{2}\right)$ を $40 \mathrm{cc} / \mathrm{min}$ にて 1 時間 流した。原料のメタンは，マスフローコントローラーで流量 制御し触媒層へと供給した。一方，純水はマイクロフィーダー を用い流量を制御し蒸発器 $\left(150^{\circ} \mathrm{C}\right)$ を経て水蒸気として触媒 層へ送入した。供給する水蒸気/メタンのモル比 (S/C) は 3.0 とした。反応温度は，触媒層内に挿入した熱電対によって 400 ${ }^{\circ} \mathrm{C} \sim 525^{\circ} \mathrm{C}$ の間で制御し，反応圧力は大気圧とした。反応生成 ガスは，水分をトラップした瑷，ガスクロマトグラフ（TCD 検出器）を用いて分析を行った。ガス分析結果より, メタン の反応率を以下のようにして求めた。

$$
\text { メタン反応率 }[\%]=\frac{\left(\mathrm{CO} \text { 濃度 }+\mathrm{CO}_{2} \text { 濃度 }\right) \times 100}{\left(\mathrm{CH}_{4} \text { 濃度 }+\mathrm{CO} \text { 濃度 }+\mathrm{CO}_{2} \text { 濃度 }\right)}(14)
$$

定常状態での各生成物の生成速度 $\mathrm{rexp}_{\mathrm{g}}[\mathrm{mol} /(\mathrm{kg}-\mathrm{cat} \cdot \mathrm{s})]$ は, ガスクロマトグラフ出ロでの全ガス流量が V $\left[\mathrm{cm}^{3} / \mathrm{min}\right](25$ ${ }^{\circ} \mathrm{C}$ ，1 $\left.\mathrm{atm}\right)$ の時，次式にて求めた。

$$
\begin{aligned}
\mathrm{r}_{\text {exp. }}= & \frac{V}{1000 \times 60} \times \frac{1}{0.082 \times 298} \times \frac{1}{\text { 触媒量 }[\mathrm{g}] \times 10^{-3}} \\
& \times \text { 各生成物の濃度 }[-]
\end{aligned}
$$

一方，反応器内の各成分の分圧については以下のように決め

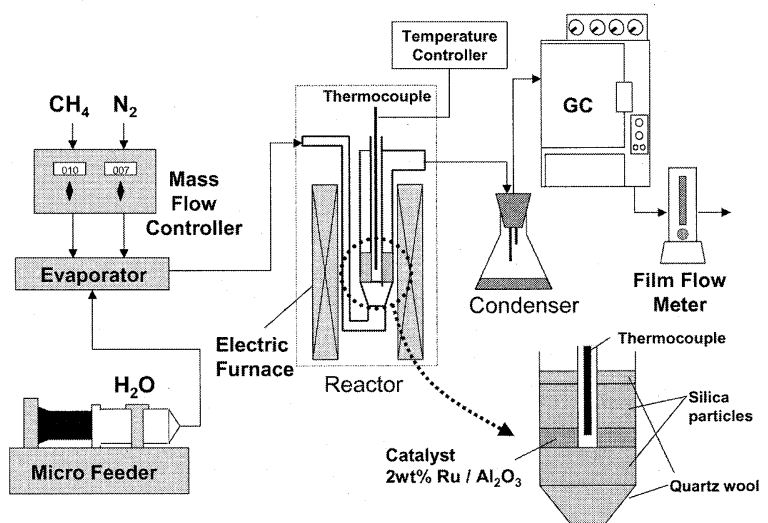

Fig. 4 Experimental set-up for the rate analysis of methane steam reforming

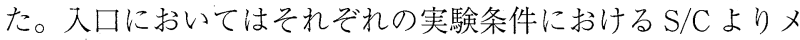
タン及び水蒸気の分圧を算出し，出口ではガスクロマトグラ フによる分析結果から各成分の分圧を計算した。水蒸気につ いては， $\mathrm{CO} ひ ゙ \mathrm{CO}_{2}$ の生成量から反応量を算出し，供給した 水蒸気量から差し引いて求めた。本研究では, 微分型反応器 として取り扱うことから反応速度解析において使用する分圧 は入口と出口の平均値を用いた。

\section{5. 結果と考察}

\section{1 反応試験結果}

反応速度解析の観点からメタン反応率が $30 \%$ 以下になるよ うに，温度，メタン供給速度，水蒸気供給速度および触媒量 を変化させた。なお，観測されたCO濃度は， $525^{\circ} \mathrm{C} て ゙ 1.3 \%$ 以 下， $500^{\circ} \mathrm{C}$ で $1.0 \%$ 以下， $475^{\circ} \mathrm{C}$ で $0.25 \%$ 以下， $450^{\circ} \mathrm{C}$ で $0.18 \%$ 以下， $425^{\circ} \mathrm{C}$ おび $400^{\circ} \mathrm{C}$ ではガスクロマトグラフ検出限界以 下であった。

まず Fig. 5 は, 反応温度 $500^{\circ} \mathrm{C}, \mathrm{S} / \mathrm{C}=3.0$ でのメタン反応 率と各ガスの発生流量の経時変化を示したものである。これ によるとメタン反応率および生成ガスの発生流量はほほ一定 で，顕著な触媒活性の劣化は見られなかった事から，こうし た定常状態でのデー夕を使用して解析を行った。念のために， 炭素質の析出の有無を確認するために, 反応終了後室温へ戻 し，空気流通下 $5{ }^{\circ} \mathrm{C} / \mathrm{min}$ で昇温しながら $\mathrm{CO}_{2}$ 分析を行った。

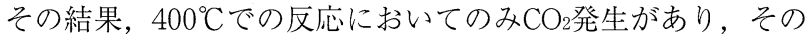
量を積算して求めたところ触媒 $1 \mathrm{~g}$ あたり $4 \times 10^{-7} \mathrm{~g}$ 相当の 炭素量であった。このことから，炭素質析出による反応への 影響は無視できるものとした。

Fig. 6は反応温度 $400^{\circ} \mathrm{C}, 450^{\circ} \mathrm{C}, 500^{\circ} \mathrm{C}$ においてメタン反応 率と $\mathrm{W} / \mathrm{F}$ (触媒重量/メタン供給速度 $\left(1 \mathrm{~atm}, 25^{\circ} \mathrm{C}\right)$ ) との 関係である。これより，反応は温度が高いほど良く進み，ま たW/Fが大きいすなわち滞在時間が長いほどメタン反応率が 大きくなることがわかる。この結果に基づいて，見掛けの初 期反応速度（ $\mathrm{W} / \mathrm{F}=0$ に扮ける接線の傾き）を求めてアレニ ウスプロットを行ったところ，その活性化エネルギーは約78 $\mathrm{kJ} / \mathrm{mol}$ となった。この值の大きさから, 本反応系では物質移 動過程ではなく反応過程に律速段階があることを示唆してい るものと判断される。

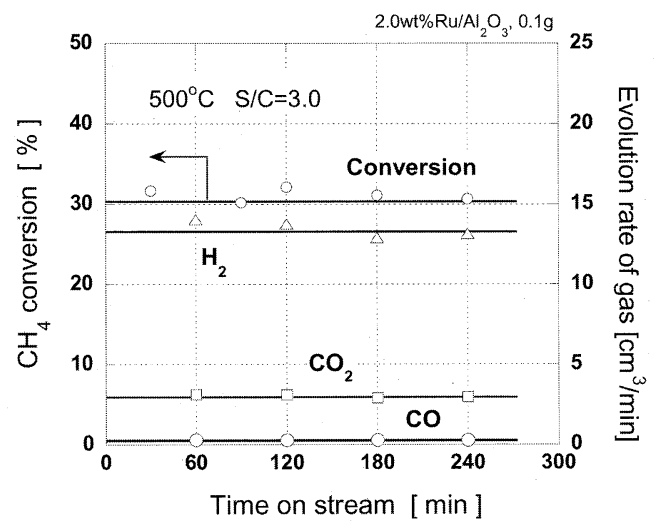

Fig. 5 Changes in the methane conversion and the evolution rates of gases with time 


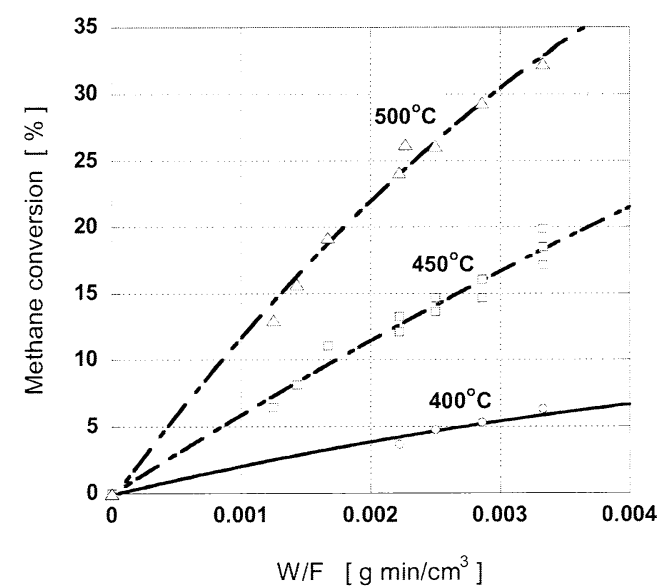

Fig. 6 Changes in the methane conversion with varying W/F at three different temperatures

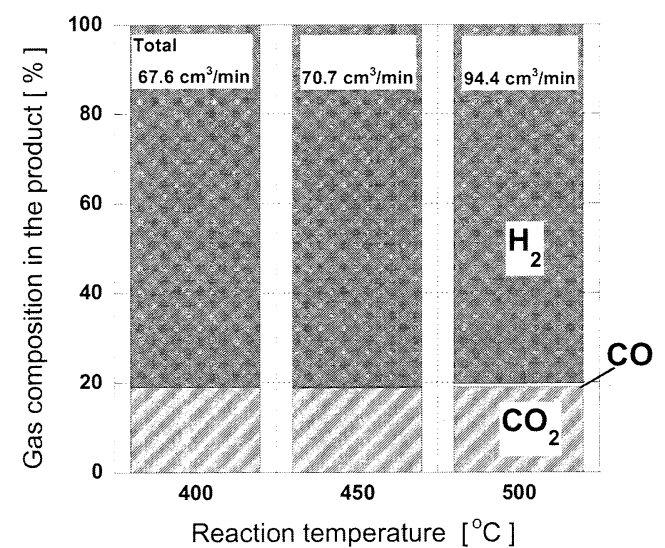

Fig. 7 Composition and total flow rate of the product gases with varying temperature $\left(\mathrm{W} / \mathrm{F}=2.2 \times 10^{-3}\right)$

Fig. 7 にはW/F $=0.0022 \mathrm{~g} \cdot \mathrm{min} / \mathrm{cm}^{3}$ における反応温度 400 , $450,500^{\circ} \mathrm{C}$ における反応ガス組成を示した。この結果より，温 度が上昇するにつれてやや増加するもののCOの発生量は少な く, $\mathrm{H}_{2} /\left(\mathrm{CO}+\mathrm{CO}_{2}\right)$ 比はほぼ4であることがわかる。 $\mathrm{CO}$ の発 生量が減少したのは，平衡計算結果からも予測されるように， 反応 (1)が抑制される一方で温度が下がる事で発熱反応である 反応 (2)の反応が促進されたためである。

\section{2 表面反応律速モデルとの比較}

$\mathrm{Ru} / \mathrm{Al}_{2} \mathrm{O}_{3}$ 触媒を用いメタンによる水蒸気改質反応を $500^{\circ} \mathrm{C}$ で行い，実測した反応速度 $\mathrm{r}_{\mathrm{exp}}$.と各モデルに基づいて算出した

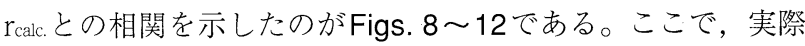
に生成したCO濃度は上記したように十分小さいことから，反 応 (3) を対象反応とした点に対して妥当性があることが確認で きる。なお，各反応モデル式に含まれるパラメー夕は，非線 形最小自乗法によって得た。

まず，Figs. 8，9には，それぞれMODEL I，Ｉによる相関 結果を示した。 rexp.と r calc.とが一致する対角線上にプロットが 集まってくればモデルとして妥当性が高いと言える。MODEL I ，IIによる相関結果を見ると，共に分散が小さくないこと から，これらのモデルは適当でないと判断した。次に，Fig. 10
にはMODEL IIIに基づくプロットを示したが比較的良好な相 関性を示した。Fig. 11はMODELNによる相関であるが，対角 線からのプロットの分散が大きく, 気相からの水蒸気の反応 への直接関与は可能性が小さい事が推測される。Fig. 12 は MODELVすなわちルテニウム触媒に対して提案された速度式

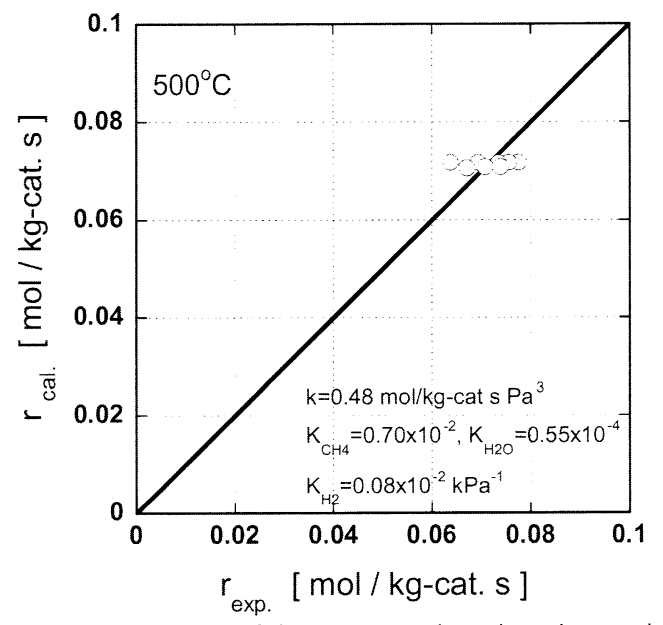

Fig. 8 Correlation plots of the measured against the model reaction rates (Model I)

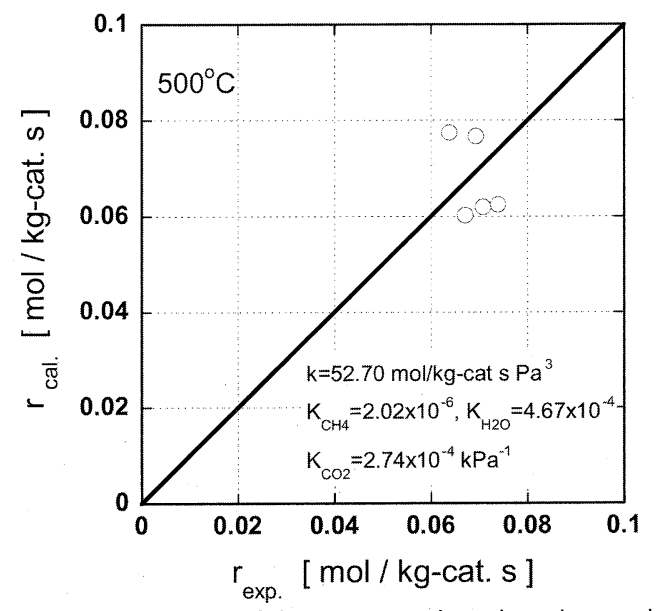

Fig. 9 Correlation plots of the measured against the model reaction rates (Model II)

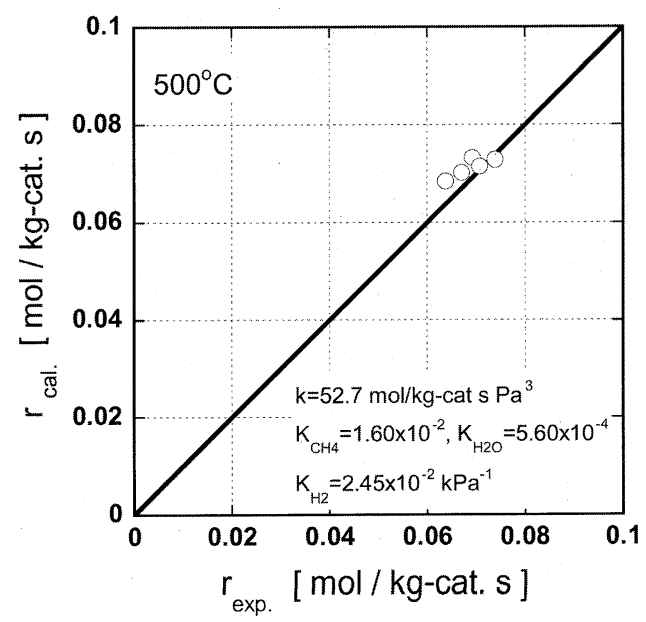

Fig. 10 Correlation plots of the measured against the model reaction rates (Model III) 


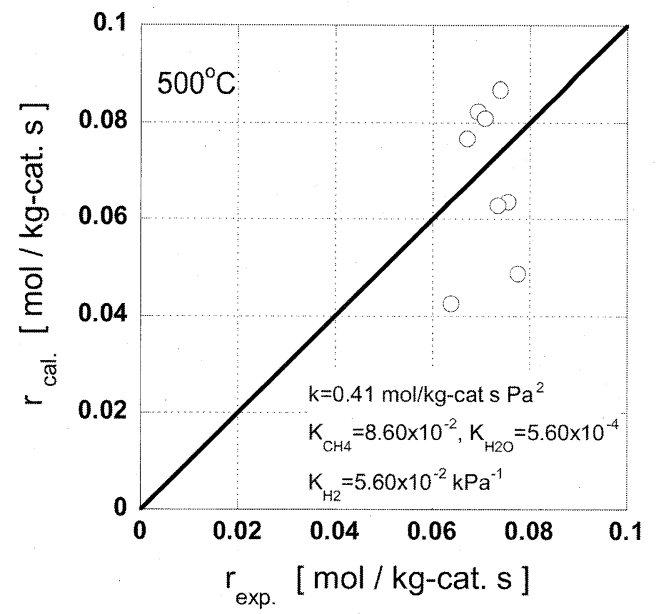

Fig. 11 Correlation plots of the measured against the model reaction rates (Model IV)

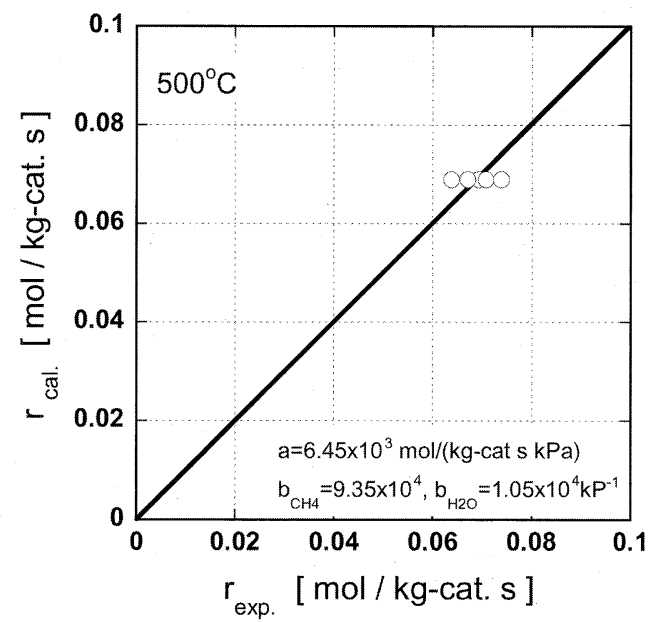

Fig. 12 Correlation plots of the measured against the model reaction rates (Model V)

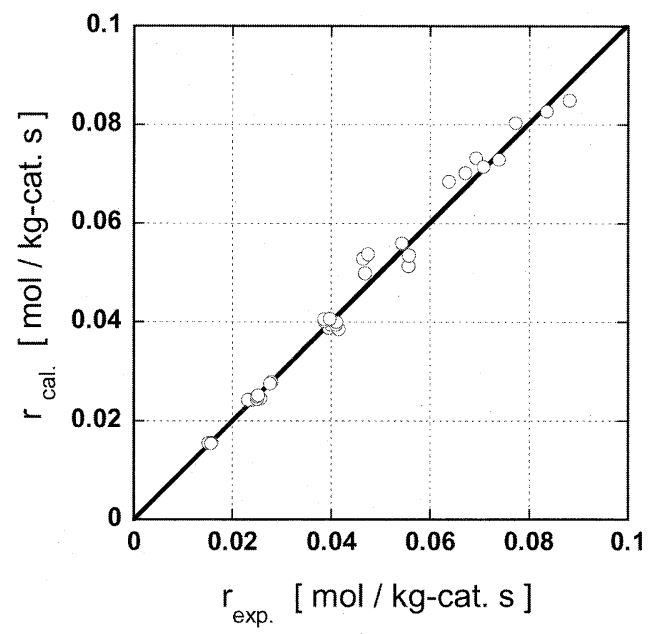

Fig. 13 Whole correlation plots of the measured against the model reaction rates according to Model III

（式(5)）に従って本実験結果を相関したものである。相関性 は MODEL III と比べて劣ることは明白である。以上の事から 本研究では MODEL IIIすなわち吸着メタンと吸着水蒸気との 表面反応を律速段階とする反応機構に基づいて導出される反
応速度式を採用することとした。Fig. 13は, 全反応温度に対 して行った実験結果を MODEL IIIによって相関したものであ るが，本モデルの妥当性を確認することができる。

\section{3 反応速度定数と吸着平衡定数の温度依存性}

MODELIIIに基づいて，反応温度400，425，450，475，500， $525^{\circ} \mathrm{C}$ においてメタン反応率 $10 \%$ 近傍にある実測值を用い，反 応速度定数や吸着平衡定数の温度依存性を調べた。その結果 をまとめたのが Fig. 14で, 総括的な反応速度定数 $\mathrm{k}[\mathrm{mol} / \mathrm{kg}-$ cat·s· $\left.\mathrm{Pa}^{3}\right]\left(=k^{\prime} K_{\mathrm{CH}_{4}} K_{\mathrm{H}_{2}} \mathrm{O}^{2}\right)$ のアレニウスプロットおよびメ 夕ン吸着平衡定数 $\mathrm{K}_{\mathrm{CH}_{4}}\left[\mathrm{~Pa}^{-1}\right]$, 水蒸気の吸着平衡定数 $\mathrm{K}_{\mathrm{H}_{2} \mathrm{O}}$ $\left[\mathrm{Pa}^{-1}\right]$, 水素の吸着平衡定数 $\mathrm{K}_{\mathrm{H}_{2}}\left[\mathrm{~Pa}^{-1}\right]$ のファントホッフ プロットを示した。各吸着平衡定数の温度依存性より吸着熱 はいずれも発熱で, メタン $\left(\Delta \mathrm{H}_{\mathrm{CH}_{4}}\right)$ が $17.9 \mathrm{~kJ} / \mathrm{mol}$, 水蒸気 $(\Delta$ $\left.\mathrm{H}_{\mathrm{H}_{2} \mathrm{O}}\right)$ が $20.9 \mathrm{~kJ} / \mathrm{mol}$, 水素 $\left(\Delta \mathrm{H}_{2}\right)$ が $10.7 \mathrm{~kJ} / \mathrm{mol}$ となったこ とから, 物理吸着のレベルであることが推察される ${ }^{23)}$ 。また 総括反応速度定数 $\mathrm{k}$ の活性化エネルギー $\mathrm{E}$ は $65.2 \mathrm{~kJ} / \mathrm{mol}$ と求 まるが，k’に対する活性化エネルギー $\mathrm{E}^{\prime} （ \mathrm{E}^{\prime}=\mathrm{E}+\Delta \mathrm{H}_{\mathrm{CH}_{4}}+2$ $\Delta \mathrm{H}_{\mathrm{H}_{2} \mathrm{O}}$ )を算出すると $125 \mathrm{~kJ} / \mathrm{mol}$ となり，反応 (3) に対する 800 $\mathrm{K}$ に扔ける反応熱 $186 \mathrm{~kJ} / \mathrm{mol}^{24)}$ の 7 割近い值となり, 表面反 応過程が律速段階にあることを示唆しているものと考えられ る。さらに詳細な確証を得るためには表面吸着種の同定とそ の挙動を表面化学的に明らかにしていく必要があるであろう。

今回決定した速度式 (式(11)) は分母の吸着項に原料のメ タンと水蒸気を含み, しかも, その 4 乗であることから, 初 期反応速度の反応圧力依存性については定性的に次のように なる。低圧域では, 分母の項の寄与が小さいために圧力（濃 度）の上昇とともに速度は大きくなるが，数気圧付近で最大 になった後は分母の項の寄与が大きくなるために速度は小さ くなっていく。すなわち，本反応系の場合，数気圧以下の条 件で反応を行うことが速度論的に有利であると予想される。

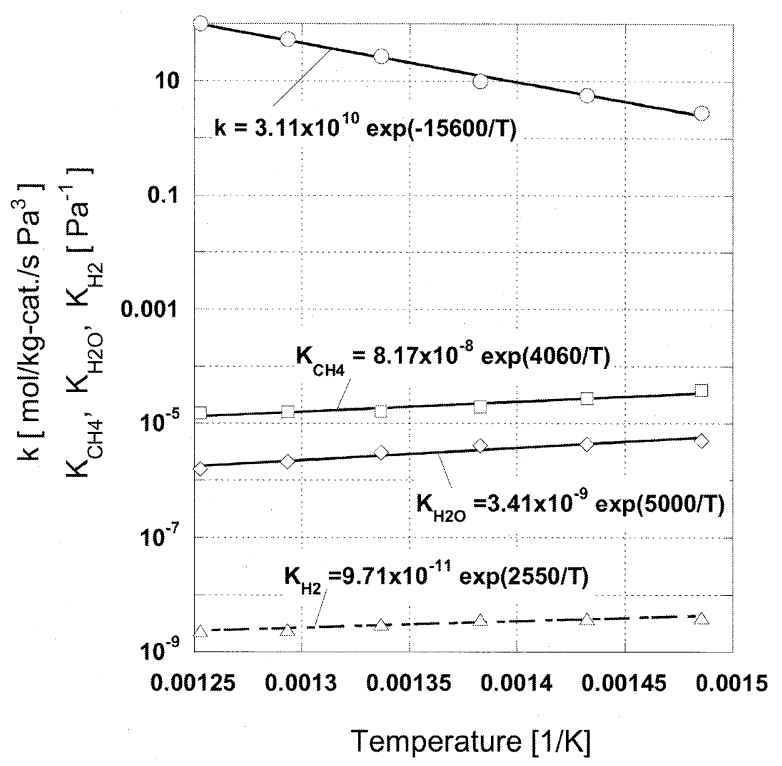

Fig. 14 Arrhenius plots of the kinetic parameters determined 


\section{6. 結 論}

メタンの低温水蒸気改質よる水素製造の反応速度式を求め るために反応実験および速度解析を行った。使用した $2.0 \mathrm{wt} \%$ $\mathrm{Ru} / \mathrm{Al}_{2} \mathrm{O}_{3}$ 担持触媒は, 大気圧下 $400 \sim 525^{\circ} \mathrm{C}$ おいて改質反応 活性を示した。反応平衡計算の結果，この温度範囲において はCO 濃度は十分小さく，かつ実験的にも確認できたことか ら，反応速度解析では次の反応を対象として取り上げた。

$\mathrm{CH}_{4}+2 \mathrm{H}_{2} \mathrm{O} \rightarrow \mathrm{CO}_{2}+4 \mathrm{H}_{2}$

反応モデルは，気相系固体触媒反応に対して活性点への反 応種の吸着と表面反応を考慮して導いた 4 つの反応モデルに 対する速度式とルテニウム触媒に対して提案されている速度 式の検証を実験的に行った。その結果，次のようなLangmuir - Hinshelwood 型の速度式が実験結果をより良く説明できる ことを見出した。

$$
\begin{aligned}
& r= \\
& \frac{k}{\left(1+K_{\mathrm{CH}_{4}} P_{\mathrm{CH}_{4}}+K_{\mathrm{H}_{2} \mathrm{O}} P_{\mathrm{H}_{2} \mathrm{O}}+K_{\mathrm{H}_{2}} P_{\mathrm{H}_{2}}\right)^{4}}\left(P_{\mathrm{CH}_{4}} P_{\mathrm{H}_{2} \mathrm{O}}{ }^{2}-\frac{P_{\mathrm{CO} 2} P_{\mathrm{H}_{2}}{ }^{4}}{K_{D}}\right)
\end{aligned}
$$

\section{文 献: References}

1）岩本雄二，膜，29,258(2004)

2) Yu, W., Ohmori, T., Yamamoto, T., Endo, A., Nakaiwa, M., Hayakawa, T., Itoh, N., Int. J. Hydrogen Energy, 30, 1071 (2005)

3) Ashcroft, A. T., Green, M. L. H., Veron, P. D. F., Nature, 344 (1990)

4）沼口徹，ペトロテック，22, 765 (1999), 23, 670(2000)

5) Sato, A., Menedez, M., Monzon, A., Santamaria, J., Miro, E. E., Lombardo, E. A., J. Catal., 158, 83 (1996)

6) 竹平勝臣, 触媒, 43, 244(2001)

7) Tsang, S. C., Claridge, J. B., Green, M. L. H., Catal. Today, 23, 3 (1995)
8) 進藤益男, 久保田宏, 明畠高司, 化学反応操作設計, (槙書 店), (1962)

9）川合智, 尾上薰, 今村易弘, 物理化学による化学工学基礎, (槙書店), (1996)

10）橋本健治, 萩野文丸, 現代化学工学, (産業図書出版), (2001)

11) Akres, W. W., Camp, D. P., AIChE J., 1, 471 (1955)

12) Munster, P., Grabke, H. J., J. Catal., 72, 279(1981)

13) Bodrov, I. M., Apel'baum, L. O., Temkin, M. I., Kinet. Katal., 9, 1065 (1968)

14) Quach, T. Q. P., Rouleau, D., J. Appl. Chem. Biotechnol., 25, 445 (1975)

15) Numaguchi, T., Kikuchi, K., Chem. Eng. Sci., 43, 2295 (1988)

16) Xu, J., Froment, G. F., AIChE J., 35, 88 (1989)

17) Dicke, A. L., Pointon, K. D., Siddle, A., J. Power Sources, 86, $523(2000)$

18) Jarosch, K., El Solh, T., de Lasa, H. I., Chem. Eng. Sci., 57, 3439 (2002)

19) Hou, K., Hughes, R., Chem. Eng. J., 82, 311 (2001)

20) Kleinert, A., Grubert, G., Pan, X., Hamel, C., SeidelMorgenstern, A., Caro, J., Catal. Today, 104, 267 (2005)

21) Hoang, D. L., Chan, S. H., Ding, O. L., Chem. Eng. J., 112, 1 (2005)

22) Berman, A., Karn, R. K., Epstein, M., Appl. Cat. A: General, 282, 73(2005)

23）斯波忠夫，慶伊富長，尾崎萃，触媒化学概論，(共立全書), (1968)

24) Stull, D. R., Westrum, E. F., Sinke, G. C., "The Chemical Thermodynamics of Organic Compounds" (1969) 